\title{
Evaluation of Some Promising Sugarcane Varieties for Yield, Quality and Natural Infection with Pokkah Boeng Disease under Different Row Spacing
}

\author{
Galal MOA ${ }^{*}$, Osman MAM${ }^{2}$ and Ali AMK ${ }^{1}$ \\ ${ }^{1}$ Agronomy Dept Sugar Crop Res Inst, ARC, Giza, Egypt \\ ${ }^{2}$ Plant Pathology \& Entomology Dept, Sugar Crops Research Inst, ARC, Giza, Egypt
}

*Corresponding author: Mohamed OA Galal, Agronomy Dept Sugar Crop Res Inst, ARC, Giza, Egypt, Email: maweias2007@gmail.com

\section{Research Article \\ Volume 3 Issue 9}

Received Date: September 22, 2018

Published Date: October 11, 2018

\section{Abstract}

The experiment was conducted at El-Mattana Research Station (latitude of $25.25^{\circ} \mathrm{N}$ and longitude of $32.31^{\circ} \mathrm{E}$ ), Agricultural Research Center, Luxor Governorate, Egypt on a plant cane in 2016/2017 and its 1st ratoon in 2017/2018 to evaluate the performance of four promising sugarcane varieties viz. 'G.2004-27', 'G.84-47', 'G.2003-47' and 'C.57-14' compared to the commercial 'G.T.54-9' variety for yield, quality and natural infection with pokkah boeng disease (Fusarium moniliforme Sheldon) under three inter-row spacing (80, 100 and $120 \mathrm{~cm}$ ). The studied combinations were randomly distributed in a randomized complete block design in a split-plot distribution, with three replications, where, inter-row spacing were allocated in the main plots, while sugarcane varieties were randomly distributed in the sub-plots. The results indicated that planting sugarcane in rows spaced at $100 \mathrm{~cm}$ attained significant increases in the number of millable canes/ha, stalk length, stalk weight, sucrose $\%$, sugar recovery $\%$ and cane and sugar yield/ha in the plant and 1 st ratoon cane crops as well as purity \% in the plant cane. Brix\% was not affected by inter-row spacing in both seasons. Moreover, insignificant difference was found between 80 and $100 \mathrm{~cm}$ inter-row spacing in the stalk weight, cane yield and sugar recovery $\%$ in the plant cane as well as stalk length, stalk weight, sucrose and sugar recovery $\%$ in the 1 st ratoon crop. Increasing inter-row spacing from 80 to $120 \mathrm{~cm}$ led to a significant reduction in disease severity \% of pokkah boeng disease in the plant and 1st ratoon crops. The promising sugarcane variety 'G.2003-47' showed the significant superiority in the number of millable canes/ha and quality traits. The promising sugarcane 'G.2004-27' variety surpassed the other ones in stalk length, stalk weight as well as cane and sugar yields/ha in the plant and 1st ratoon cane. Also, it recorded the lowest percentage of infection with pokkah boeng disease (Fusarium moniliforme Sheldon). However, the difference between "G.2004-27" and 'G.2003-47' in the number of millable canes/ha in the 1st ratoon cane 


\section{Open Access Journal of Agricultural Research}

and brix \%, purity $\%$ and sugar recovery $\%$ in the plant cane as well as disease severity $\%$ of pokkah boeng disease in the plant and $1^{\text {st }}$ ratoon crop were insignificant.

Under conditions of this investigation, planting sugarcane variety 'G.2004-27' in rows spaced at $100 \mathrm{~cm}$ can be recommended to obtain the highest cane and sugar yields/ha and the lowest percentage of infection with pokkah boeng disease (Fusarium moniliforme Sheldon).

Keywords: Quality; Row Spacing; Sugarcane Varieties; Yield; Pokkah Boeng

\section{Introduction}

Yield potential of a variety can be achieved by manipulating agronomic practices. Among the various agronomic managements, row spacing influences the productivity of sugarcane by maintaining optimum stalk population per unit area. Planting geometry plays an important role in water use efficiency, interception of solar radiation and evaporation. Row spacing ensures more uniform allocation of plants in an area and makes canopy of plant more efficient in intercepting radiant energy. In Egypt, the commercial cane variety 'G.T.54-9' occupies most of the area planted with sugarcane. Recently, Sugar Crops Research Institute developed a lot of promising varieties of sugarcane, among them 'G.200427', 'G.84-47' and 'G.2003-47'. The newly bred varieties showed variable response to different agronomic practices. In this respect, Ahmed, et al pointed out that the difference between the evaluated varieties in the number of millable canes/ha, millable cane height, sucrose and sugar yield was insignificant, when they were grown in rows of 80 and $100-\mathrm{cm}$ width [1]. They added that the promising sugarcane variety 'G.95-21' significantly surpassed the other promising ones in the number of millable canes/ha, millable stalk height, total soluble solids percentage and cane yield/ha. They mentioned that planting 'G.95-21' sugarcane variety in rows spaced at $100 \mathrm{~cm}$ can be recommended to obtain the highest cane and sugar yield/ha. El-Shafai and Ismail found that planting cane at $90 \mathrm{~cm}$ inter- row spacing recorded the highest values of stalk height and number of millable canes/ha, while it gave the highest net cane yield in the plant cane only [2]. The commercial cv. 'G.T.54-9' recorded the highest averages of stalk height, number of millable canes, cane and sugar yields/ha, while higher sucrose $\%$ and sugar recovery $\%$ were given by 'Ph.8013'. El-Sogheir and Abd El-Fattah stated that planting sugarcane in rows of 90 and/or $100-\mathrm{cm}$ inter-row spacing gave the highest cane and sugar yields in both season and sugar recovery $\%$ in the $1^{\text {st }}$ one [3]. The highest juice purity\% was obtained from canes grown in rows spaced at $100 \mathrm{~cm}$. They recommended growing 'G.T.54-9' variety in rows spaced at 90 or $100 \mathrm{~cm}$ to obtain the highest cane and sugar yields/ha. El-Geddawy, et al, Galal, et al. and ElBakry revealed that the promising sugarcane variety 'G.2003-47'showed the significant superiority in juice quality traits. Banerjee, et al got the highest ratoon cane yield by planting sugarcane in rows of $90-\mathrm{cm}$ spacing followed by 60 and $110-\mathrm{cm}$ [4-7]. They obtained the highest ratoon cane yield from 'COB 94164' cane variety grown at row spacing of $90 \mathrm{~cm}$. El-Geddawy, et al. and Abd El-Lattief found that narrow inter-row spacing (100 $\mathrm{cm}$ ) produced higher number of millable canes, cane and sugar yields compared to the other inter-row spacing $(120$ And $140 \mathrm{~cm})[8,9]$. They added that 'F.153' variety produced the highest number of millable cans and cane yield, while 'G.T.54-9' had the highest sugar recovery\%. Fahmy, et al showed that the differences in most of the studied traits between 'G.T.54-9' and 'G.2003-47' varieties were insignificant [10]. Also, Ph.8013 variety showed the significant superiority in stalk weight, sucrose $\%$ and sugar recovery\% over the other tested ones. However, the variance between 'Ph.8013' and 'G.2003-47' in sucrose\% and sugar recovery\% was insignificant. Chakrawal and Kumar found that the effects of planting geometry with respect to brix and purity percentages were found to be non significant [11]. However, comparatively higher values were observed under $90 \mathrm{~cm}$ row spacing. The maximum sugar yield was observed at $90 \mathrm{~cm}$ row spacing, which was higher than 30: 120, 120 and $150 \mathrm{~cm}$ row spacing, respectively. Varietal differences in respect to brix, purity, juice recovery and commercial cane sugar (CCS) percent were found to be significant and a higher value was obtained due to the variety 'CoP 9301'. Though significantly higher sugar yield was registered by 'BO 153'. There is a contradiction regarding the effect of row spacing on the quality parameters such as brix, sucrose content and CCS but Pawar, et al. supported the view that 


\section{Open Access Journal of Agricultural Research}

wider row spacing improved the sucrose content and commercial cane sugar percentage [12-14]. Sucrose contents in cane juice and CCS were not affected significantly by different row spacing. Similarly findings were recorded by Maqsood, et al. and Chitkala Devi, et al. who noticed that juice quality was not affected significantly by different row spacing $[15,16]$.

In Egypt the sugarcane crop is affected by several diseases which caused great losses in yield of cane and sugar. Pokkah boeng disease was selected in this study because of importance to the Egypt sugarcane industry, fungus disease caused by Fusarium moniliforme Sheldon Mehareb, et al. [17]. Pokkah boeng is a Javanese term, which describes a disease affecting sugarcane tops, was first recorded in Java by Walker and Went [18]. The disease becoming major disease of sugarcane in different countries of the world $[19,20]$. In recent years, the occurrence of the disease has been recorded in almost all the cane growing areas in Egypt, Osman, et al. [21]. The characteristics symptoms of pokkah boeng disease are the appearance of chlorotic patches towards the base of the young leaves, in acute cases disease shows distortion of stalk with external and internal cut like lesions and rotting of apical part of stalk. Under field conditions, the disease may develop many variations from the general symptoms, but the final result is usually a malformed or damaged top and stalk. The base of affected leaves is often narrower as compared to normal leaves. Development of such disease symptoms was observed in four phases namely, chlorotic phases I and II, top rot and knife cut phase. The apical leaves may also show pronounced wrinkling and twisting depending upon the susceptibility of varieties and existing climatic conditions. Also malformed or damaged top and stalk due to the disease was recorded, Vishwakarma, et al. and Osman [21,22].

\section{Materials and Methods}

The experiment was conducted at El-Mattana Research Station (latitude of $25.25^{\circ} \mathrm{N}$ and longitude of $32.31^{\circ}$ E), Agricultural Research Center, Luxor Governorate, Egypt on a plant cane in 2016/2017 and its 1st ratoon in $2017 / 2018$ to evaluate the performance of four promising sugarcane varieties viz. 'G.2004-27', 'G.8447', 'G.2003-47' and 'C.57-14' compared to the commercial 'G.T.54-9' variety for yield, quality and natural infection with pokkah boeng disease (Fusarium moniliforme Sheldon) under three inter-row spacing (80, 100 and $120 \mathrm{~cm}$ ). Sugarcane varieties were planted in the 2nd week of March using two rows of three-budded cuttings in planting. However, management of the first ratoon crop started during the 3rd week of March after harvesting of the plant cane.

The studied combinations were randomly distributed in a randomized complete block design in a split-plot distribution, with three replications, where, inter-row spacing were allocated in the main plots, while sugarcane varieties were randomly distributed in the sub-plots. The sub-plot area was $60 \mathrm{~m}^{2}$ (including 15, 12 and 10 rows in case of spacing them at 80,100 and $120 \mathrm{~cm}$, respectively, and $5 \mathrm{~m}$ in length).

Nitrogen fertilizer was applied as urea $(46 \% \mathrm{~N})$ at the rate of $576 \mathrm{~kg} \mathrm{~N} / \mathrm{ha}$, which was split into two equal doses in the plant cane (after the $1^{\text {st }}, 2^{\text {nd }}$ hoeing and 30 days later, i.e. 45, 75 and 105 days from planting). Nitrogen given to the first ratoon crop was split into two doses; 30 days after harvesting of the plant cane and 30 days later. Phosphorus fertilizer was added during land preparation at $72 \mathrm{~kg} \mathrm{P}_{2} \mathrm{O}_{5} /$ ha as calcium super phosphate $\left(15 \% \mathrm{P}_{2} \mathrm{O}_{5}\right)$, meanwhile, potassium fertilizer was added at $115.2 \mathrm{~kg}$ $\mathrm{K}_{2} \mathrm{O} /$ ha as potassium sulphate $\left(48 \% \mathrm{~K}_{2} \mathrm{O}\right)$ once, with the first $\mathrm{N}$-dose. The other agronomic practices for growing sugarcane were done as recommended by the Sugar Crops Research Institute.

\section{The recorded data}

1. Number of millable canes/plot was counted and converted into thousand/ha at harvest.

2. Stalk length $(\mathrm{cm})$ was measured from soil surface to the top visible dewlap.

3. Stalk fresh weight $(\mathrm{kg})$ was determined by dividing cane weight of one meter sample by its corresponding number of millable canes.

A representative sample of 20 millable cane from each plot was taken at random, stripped, cleaned and squeezed. The primary juice was extracted by electric pilot mill screened and mixed thoroughly. One liter of juice was taken in glass cylinder to estimate juice quality characteristics.

4. Total soluble solids (TSS \%) in cane juice (Brix percentage) was determined in the laboratory using brix hydrometer standardized at $20^{\circ} \mathrm{C}$.

5. Sucrose percentage was determined using Sacharemeter according to A.O.A.C [23].

6. Juice purity percentage was calculated according to the following equation:

7. Sugar recovery percentage it was calculated as follows: 


\section{Open Access Journal of Agricultural Research}

Sugar recovery $\%=[$ sucrose $\%-0.4($ brix $\%-$ sucrose $\%)$ $\times 0.73]$.

Where $\mathrm{B}=$ Brix reading, $\mathrm{S}=$ Sucrose percentage, 0.4 and 0.73 constants. Yadav and Sharma [24].

8. Cane yield/ha (ton) was determined from the fresh weight (kg) of millable canes of each plot, which was converted into ton/ha.

9. Sugar yield/ha (ton) was estimated as follows: Sugar yield (ton) $=$ cane yield (ton) $\mathrm{x}$ sugar recovery $\%$.

** Determination of the infected sugarcane promising varieties with pokkah boeng disease.

10. Disease Severity percentage of pokkah boeng disease (photo 1):
Disease Severity percentage (DS \%) of infected plants with disease mentioned above were calculated according to the following equation at harvest, Ramirez and Nass, Sidique, et al. and Osman $[19,21,25]$ :

$$
\mathrm{DS} \%=\frac{\Sigma(\mathrm{Ax} \mathrm{n})}{\Sigma \mathrm{B} \times \text { Maximum possible score }(4)} \times 100
$$

Where:

$A=$ disease scale $(0,1,2,3$ or 4$)$.

$\mathrm{n}=$ number of stalks for each disease scale.

$\mathrm{B}=$ total number of stalks.

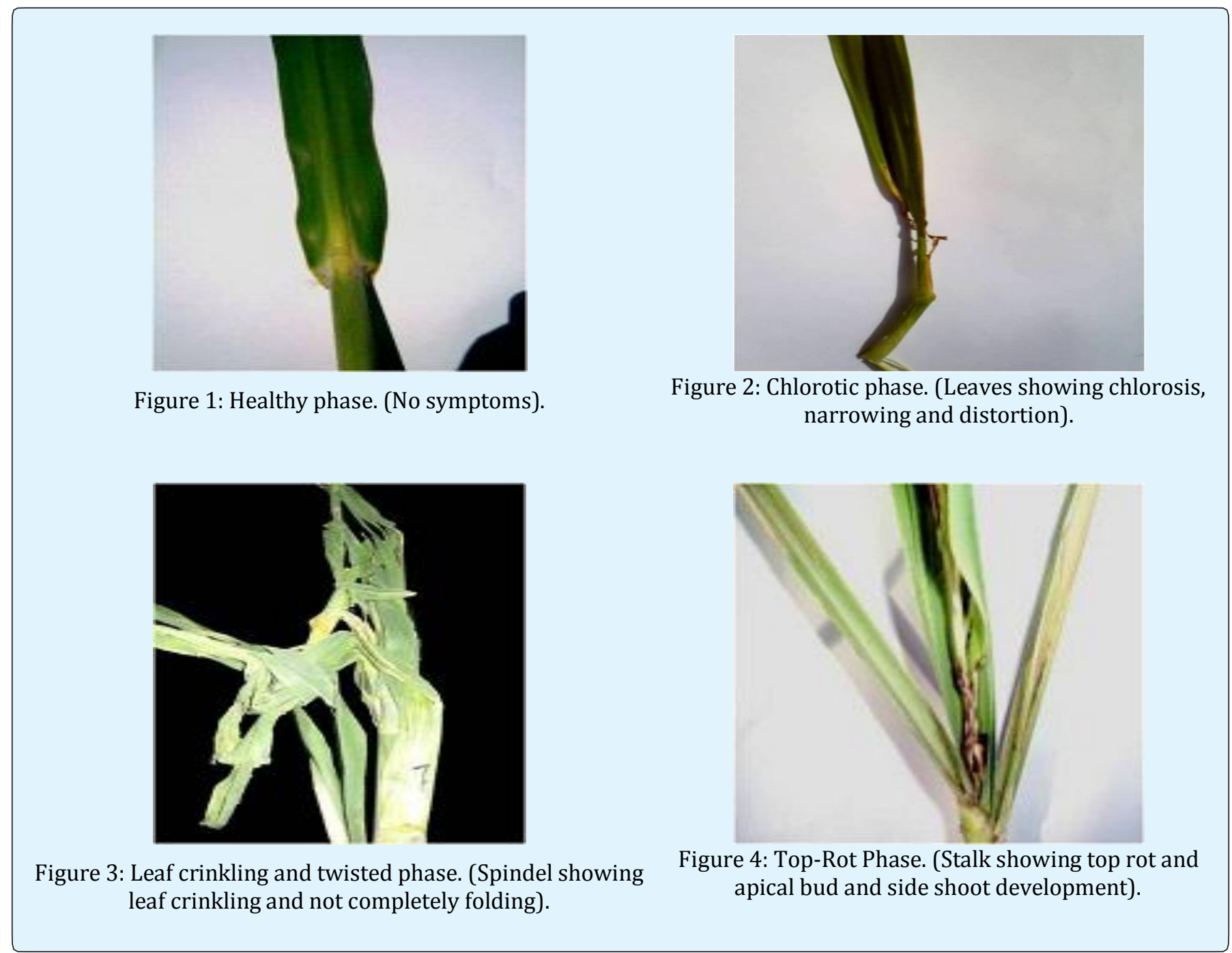




\section{Open Access Journal of Agricultural Research}
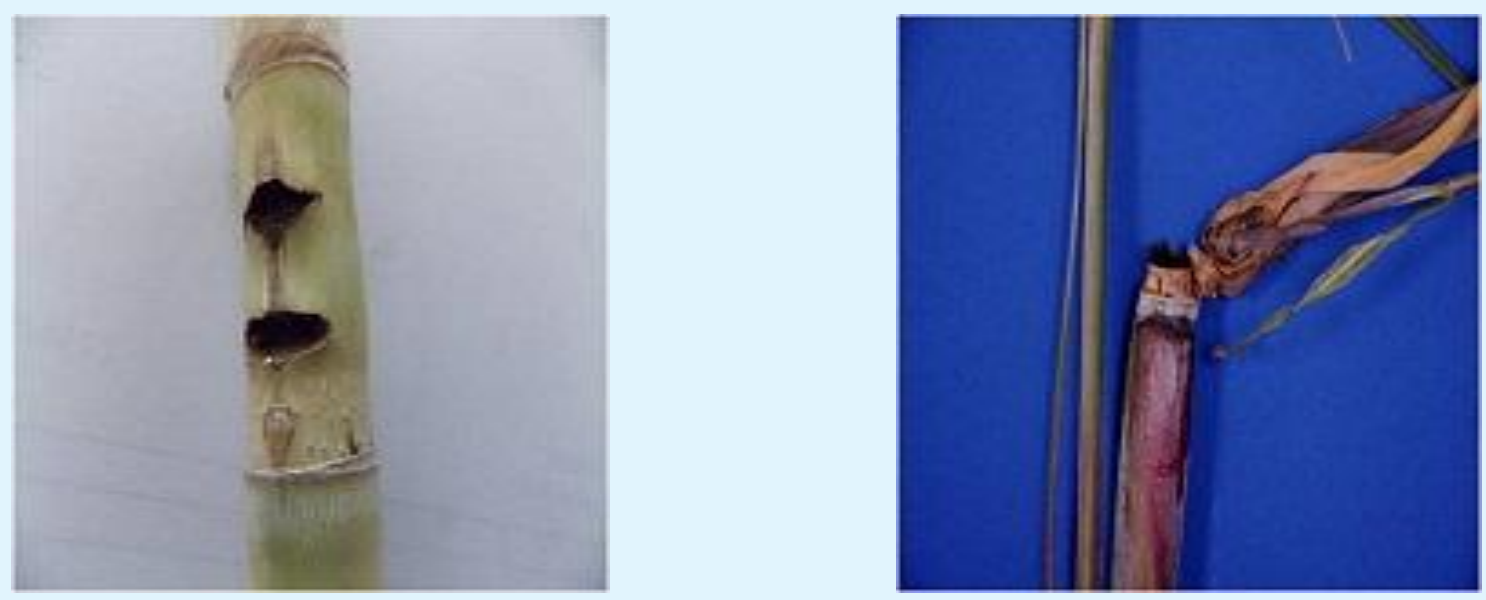

Figure 5: Knife-cut Phase. (Stalk showing terminal knife cut and side shoot development).

Photographic representation of pokkah boeng disease severity on sugarcane plants prepared by Ramirez and Nass, Sidique et al and Osman [19,21,25].

\section{Statistical Analysis}

The collected data were statistically analyzed according to the procedures outlined by Snedecor and Cochran [26]. Means of significant variance were compared using LSD test at 5\% level of probability.

\section{Results and Discussion}

\section{Number of Millable Canes/ha}

Data in Table (1) reveal that the number of millable canes/ha was significantly affected by inter-row spacing in the plant and 1st ratoon cane crops. Planting sugarcane in rows of $100 \mathrm{~cm}$ increased the number of millable canes/ha by 10.96 and 15.00 thousands/ha in the plant cane, correspond to 4.40 and 8.30 thousand millable canes/ha in 1st ratoon cane, respectively compared with that recorded in case of planting sugarcane at 80 and/or $120 \mathrm{~cm}$ inter-row spacing. Increasing number of millable canes at $100 \mathrm{~cm}$ row spacing can be referred to more number of tillers per unit area and the survival of a large number of them until harvesting. Similar results were obtained by Ahmed et al and Abd El- Lattief [1,9].

The tested sugarcane varieties differed significantly in the number of millable canes. The results in Table (1) clear that the two promising sugar cane varieties viz. 'G.2003-47' and 'G.84-47' significantly surpassed the other varieties in this trait. Moreover, it can be noticed that the difference in millable cane number/ha between 'G.2003-47' and each of 'G.84-47' and 'G.2004-27' was insignificant, in the $1^{\text {st }}$ ratoon. Varietal differences in millable cane number were reported by El-Shafai and Ismail and Fahmy, et al. [2,10].

Number of millable canes was significantly influenced by the interactions among row spacing and the tested cane varieties in the plant and 1st ratoon cane crops.

The difference in the number of millable canes between 'G.2004-27' and each 'G.2003-47' and 'G.84-47' was insignificant when they were planted in rows of 120 $\mathrm{cm}$, in the plant cane as well as at $80,100,120 \mathrm{~cm}$ in $1 \mathrm{st}$ ratoon cane, with significant variance between them at 80 and $100 \mathrm{~cm}$ in the plant cane. These results are similar to those obtained by El-Shafai and Ismail, who found that the difference in number of millable canes between 'G.T.54-9' and 'Ph.8013' was insignificant when they were planted in rows at $80 \mathrm{~cm}$, with a significant difference between the two varieties at $100 \mathrm{~cm}$ apart [2].

\section{Stalk Length}

Data in table 1 show that growing sugarcane in rows of $100 \mathrm{~cm}$ increased the stalk length by 15.93 and 25.57 $\mathrm{cm}$ in the plant cane, correspond to 7.07 and $28.97 \mathrm{~cm}$ in $1^{\text {st }}$ ratoon cane, respectively compared with that recorded in case of planting sugarcane at 80 and/or $120 \mathrm{~cm}$ interrow spacing. Meantime, the difference between 80 and $100 \mathrm{~cm}$ in stalk length was insignificant, in the 1st ratoon cane crop. More cane length at wider row spacing is also ascribed to higher light interception, better utilization of nutrients and water that might be resulted in increased crop growth rate which finally produced longer canes. These results are in line with those obtained by Ahmed, et al. [1]. 


\section{Open Access Journal of Agricultural Research}

\begin{tabular}{|c|c|c|c|c|c|c|c|}
\hline \multirow{2}{*}{\multicolumn{2}{|c|}{ Treatments }} & \multicolumn{2}{|c|}{$\begin{array}{c}\text { Number of millable } \\
\text { canes/ha (1000) }\end{array}$} & \multicolumn{2}{|c|}{ stalk length (cm) } & \multicolumn{2}{|c|}{ stalk weight (kg) } \\
\hline & & PC & FR & PC & FR & PC & FR \\
\hline \multicolumn{8}{|c|}{ Row spacing } \\
\hline \multicolumn{2}{|c|}{$80 \mathrm{~cm}$} & 114 & 127.1 & 284.9 & 302 & 1.41 & 1.3 \\
\hline \multicolumn{2}{|c|}{$100 \mathrm{~cm}$} & 125 & 131.5 & 300.9 & 309.1 & 1.47 & 1.3 \\
\hline \multicolumn{2}{|c|}{$120 \mathrm{~cm}$} & 110 & 123.2 & 275.3 & 280.1 & 1.24 & 1.08 \\
\hline \multicolumn{2}{|c|}{ LSD at 5\% level } & 4.4 & 2.4 & 5.2 & 17.5 & 0.07 & 0.12 \\
\hline \multicolumn{8}{|c|}{ Sugarcane varieties } \\
\hline \multicolumn{2}{|c|}{ ‘G.T.54-9' (V1) } & 119.5 & 125.9 & 286.2 & 293.2 & 1.3 & 1.19 \\
\hline \multicolumn{2}{|c|}{ 'G.2004-27' (V2) } & 114.4 & 130.9 & 303.6 & 315.8 & 1.67 & 1.39 \\
\hline \multicolumn{2}{|c|}{ ‘G.84-47’ (V3) } & 122.2 & 133.6 & 301.6 & 314.3 & 1.29 & 1.12 \\
\hline \multicolumn{2}{|c|}{ ‘G.2003-47’ (V4) } & 123.8 & 132.5 & 283.9 & 289.6 & 1.31 & 1.2 \\
\hline \multicolumn{2}{|c|}{ 'C.57-14' (V5) } & 101.6 & 113.6 & 259.9 & 272.5 & 1.3 & 1.23 \\
\hline \multicolumn{2}{|c|}{ LSD at $5 \%$ level } & 4.1 & 5.1 & 6 & 5.9 & 0.06 & 0.07 \\
\hline \multicolumn{8}{|c|}{ Interaction } \\
\hline \multirow{5}{*}{$80 \mathrm{~cm}$} & V1 & 120.2 & 125.9 & 281.5 & 295.5 & 1.39 & 1.38 \\
\hline & $\mathrm{V} 2$ & 110 & 130.9 & 297.7 & 319 & 1.68 & 1.36 \\
\hline & V3 & 125 & 135.9 & 295 & 317.5 & 1.36 & 1.27 \\
\hline & V4 & 125 & 136.9 & 285 & 293 & 1.38 & 1.25 \\
\hline & V5 & 90 & 106 & 265.5 & 285 & 1.26 & 1.25 \\
\hline \multirow{5}{*}{$100 \mathrm{~cm}$} & V1 & 123.3 & 125.9 & 313.7 & 317 & 1.31 & 1.27 \\
\hline & V2 & 123.3 & 133.9 & 315.7 & 327.3 & 1.73 & 1.51 \\
\hline & V3 & 131.7 & 135.9 & 315.7 & 325.3 & 1.38 & 1.15 \\
\hline & V4 & 136.6 & 138.6 & 290.7 & 296.7 & 1.47 & 1.27 \\
\hline & V5 & 110 & 123.3 & 268.7 & 279 & 1.46 & 1.29 \\
\hline \multirow{5}{*}{$120 \mathrm{~cm}$} & V1 & 115 & 125.9 & 263.5 & 267 & 1.19 & 0.93 \\
\hline & $\mathrm{V} 2$ & 110 & 127.9 & 297.5 & 301 & 1.61 & 1.3 \\
\hline & V3 & 110 & 128.9 & 294 & 300 & 1.14 & 0.95 \\
\hline & V4 & 110 & 121.9 & 276 & 279 & 1.07 & 1.08 \\
\hline & V5 & 105 & 111.5 & 245.5 & 253.5 & 1.2 & 1.15 \\
\hline \multicolumn{2}{|c|}{ LSD at $5 \%$ level } & 6.8 & 8.4 & 9.9 & 10.3 & 0.11 & 0.12 \\
\hline
\end{tabular}

Table 1: Number of millable canes, stalk length and stalk fresh weight of the tested sugarcane varieties as affected by inter-row spacing and their interactions, in the plant cane, PC (2016-2017) and its 1st ratoon crop, FR (2017-2018).

The results in Table 1 exhibit that the promising variety 'G.2004-27' gave the tallest millable canes in the plant and 1st ratoon cane, without appreciable variance with that produced by 'G.84-47' in this trait. Also, insignificant difference in stalk length was observed between the commercial variety 'G.T.54-9' and promising variety 'G.2003-47' in this trait, in the plant and 1st ratoon cane. Meanwhile, it was found that ' $\mathrm{C}$. 57.14' variety had the shortest millable canes, in the plant and 1st ratoon cane. Differences among cane varieties in stalk length were reported by El-Geddawy, et al. [4].
Stalk length was significantly influenced by the interactions between the tested cane varieties and interrow spacing in the plant and 1st ratoon cane, there was insignificant variance between 'G.2004-27' and 'G.84-47' in stalk length in sugarcane grown in rows spaced at 100 $\mathrm{cm}$, in the plant and 1st ratoon crop as well as at 80 and $120 \mathrm{~cm}$. However, the difference between the two varieties and the commercial variety 'G.T.54-9' was insignificant when they were planted in rows at $100 \mathrm{~cm}$, with significant variance between the two varieties and commercial variety 'G.T.54-9' at 80 and $120 \mathrm{~cm}$ inter-row spacing, in the plant and 1st ratoon cane. These results are similar to those obtained by El-Bakry who found that 


\section{Open Access Journal of Agricultural Research}

the commercial variety 'G.T.54-9' gave the tallest millable canes for in plant cane when row spacing was $100 \mathrm{~cm}$ however, 'G.T.54-9' variety produced the highest value $(267.00 \mathrm{~cm})$ in first ratoon with row spacing of $120 \mathrm{~cm}$ [6].

\section{Stalk Fresh Weight}

Data in Table 1 illustrate that stalk weight was largely affected by inter- row spacing in the plant and 1st ratoon cane crops. Planting sugarcane in rows of $100 \mathrm{~cm}$ interrow spacing gave the highest stalk weight (1.47 and 1.30 $\mathrm{kg}$ ) compared with recorded in case of planting sugarcane at 80 and/or $120 \mathrm{~cm}$ in the plant and 1st ratoon cane crop, successively. Moreover, the difference between 80 and $100 \mathrm{~cm}$ in stalk weight was insignificant, in the plant and 1st ratoon cane crops. The variation in weight per cane is attributed to variation in cane length attained during the crop growth period in different planting patterns. The results are in conformity with those of Maqsood, et al. [15].

The results clear that the promising sugarcane variety 'G.2004-27' gave the highest stalk weight (1.67 and 1.39 $\mathrm{kg}$ in the plant and 1st ratoon cane, respectively) compared with the other varieties. However, the difference between the commercial variety 'G.T.54-9' and each 'G.2003-47' and 'C.57-14' varieties was insignificant in this trait, in the plant and 1st ratoon cane. Meanwhile, it was found that the sugarcane variety 'G.84-47' had the least stalk weight, in the plant and 1st ratoon cane. The same finding was reported by Galal, et al. who found that sugarcane variety 'G.84-47' recorded the least weight for stalk in both seasons [5]. This could be attributed to its recorded values of stalk length.

The interaction between inter-row spacing and the tested cane varieties had a significant influence on stalk weight in the plant and 1st ratoon cane. The difference in the stalk weight between 'G.2003-47' and 'G.84-47' was insignificant when they were planted in rows of 80 and
$100 \mathrm{~cm}$, in the plant and $1^{\text {st }}$ ratoon cane as well as at 120 $\mathrm{cm}$ in the plant cane, with significant variance between them at $120 \mathrm{~cm}$ in the $1^{\text {st }}$ ratoon cane.

\section{Brix Percentage}

Data in Table (2) indicated that brix\% was insignificant affected by inter-row spacing and the interaction between inter-row spacing and the tested cane varieties in the plant and 1st ratoon cane. This result coincides with those obtained by Maqsood, et al. and Chitkala Devi, et al. [15,16].

The tested sugarcane varieties differed markedly in the brix\%. The results in Table 2, manifested that 'G.200347 ' sugarcane variety gave the highest brix $\%$ in the plant and 1st ratoon cane. However, the difference in brix \% between 'G.2003-47' and each 'G.2004-27', 'G.84-47' and the commercial variety 'G.T.54-9' was insignificant, in the plant cane. Meanwhile, it was found that 'C.57.14' variety had the lowest brix \%, in the plant and $1^{\text {st }}$ ratoon cane. The differences between the studied varieties with respect to brix value may be mainly due to gene make-up the differences, in the addition to, the surrounding environmental conditions prevailing during the formation period of soluble solids. The same results reported by Galal, et al. (2017) and El-Bakry [6].

\section{Sucrose Percentage}

Data in Table 2 show that the sucrose\% was significantly affected by inter-row spacing in the plant and 1 st ratoon cane crops. Growing sugarcane in rows of 100 $\mathrm{cm}$ increased the sucrose $\%$ by 2.05 and $1.61 \%$ in the plant cane and 0.45 and $1.11 \%$ in 1st ratoon cane, respectively, compared with that recorded in planting sugarcane at 80 and/or $120 \mathrm{~cm}$ inter-row spacing. However, the difference between 80 and $100 \mathrm{~cm}$ in their influence on sucrose \% was insignificant, in the 1st ratoon cane. These results are in agreement with those obtained by Ahmed, et al. Pawar, et al. [1,14].

\begin{tabular}{|c|c|c|c|c|c|c|c|c|}
\hline \multirow{2}{*}{ Treatments } & \multicolumn{2}{|c|}{ Brix \% } & \multicolumn{2}{|c|}{ Sucrose \% } & \multicolumn{2}{|c|}{ Purity \% } & \multicolumn{2}{|c|}{ Sugar recovery \% } \\
\hline & PC & FR & PC & FR & PC & FR & PC & FR \\
\hline \multicolumn{9}{|c|}{ Row spacing } \\
\hline $80 \mathrm{~cm}$ & 19.54 & 19.23 & 14.62 & 16.05 & 74.57 & 83.47 & 9.21 & 10.79 \\
\hline $100 \mathrm{~cm}$ & 19.25 & 19.42 & 16.67 & 16.5 & 87.48 & 84.96 & 11.46 & 11.19 \\
\hline $120 \mathrm{~cm}$ & 19.33 & 18.66 & 15.06 & 15.38 & 77.73 & 82.4 & 9.74 & 10.27 \\
\hline LSD at $5 \%$ level & NS & NS & 0.55 & 0.73 & 7.52 & NS & 0.59 & 0.72 \\
\hline \multicolumn{9}{|c|}{ Sugarcane varieties } \\
\hline ‘G.T.54-9' (V1) & 19.52 & 18.82 & 15.45 & 15.55 & 79.17 & 82.61 & 10.09 & 10.4 \\
\hline ‘G.2004-27' (V2) & 19.31 & 19.2 & 15.62 & 15.75 & 81.32 & 82.01 & 10.35 & 10.49 \\
\hline
\end{tabular}




\section{Open Access Journal of Agricultural Research}

\begin{tabular}{|c|c|c|c|c|c|c|c|c|c|}
\hline \multicolumn{2}{|c|}{ ‘G.84-47' (V3) } & 19.61 & 18.93 & 15.26 & 15.94 & 78.09 & 84.21 & 9.87 & 10.76 \\
\hline \multicolumn{2}{|c|}{ ‘G.2003-47’ (V4) } & 19.77 & 19.78 & 16.48 & 17.31 & 83.34 & 87.56 & 11.07 & 11.91 \\
\hline \multicolumn{2}{|c|}{ ‘C.57-14' (V5) } & 18.66 & 18.79 & 14.44 & 15.35 & 77.7 & 81.68 & 9.31 & 10.2 \\
\hline \multicolumn{2}{|c|}{ LSD at 5\% level } & 0.59 & 0.46 & 0.54 & 0.47 & 3.5 & 2.75 & 0.56 & 0.46 \\
\hline \multicolumn{10}{|c|}{ Interaction } \\
\hline \multirow{5}{*}{$80 \mathrm{~cm}$} & V1 & 19.36 & 19 & 15.03 & 16.06 & 77.67 & 84.51 & 9.71 & 10.86 \\
\hline & V2 & 19.61 & 19.8 & 14.99 & 15.79 & 76.46 & 79.73 & 9.59 & 10.36 \\
\hline & V3 & 19.67 & 19.25 & 13.26 & 16.35 & 66.32 & 85.03 & 7.72 & 11.08 \\
\hline & V4 & 20 & 19.9 & 16.2 & 17.18 & 81.01 & 86.35 & 10.72 & 11.75 \\
\hline & V5 & 19.05 & 18.2 & 13.6 & 14.88 & 71.39 & 81.75 & 8.34 & 9.89 \\
\hline \multirow{5}{*}{$100 \mathrm{~cm}$} & V1 & 19.6 & 18.87 & 16.34 & 15.58 & 83.43 & 82.6 & 10.98 & 10.42 \\
\hline & V2 & 19.23 & 19.6 & 17.11 & 16.63 & 90.27 & 84.87 & 11.95 & 11.27 \\
\hline & V3 & 19.67 & 19.13 & 17.51 & 16.9 & 90.85 & 88.35 & 12.25 & 11.69 \\
\hline & V4 & 19.8 & 19.83 & 17.02 & 17.27 & 86.89 & 87.15 & 11.68 & 11.86 \\
\hline & V5 & 17.97 & 19.67 & 15.36 & 16.1 & 85.94 & 81.85 & 10.45 & 10.71 \\
\hline \multirow{5}{*}{$120 \mathrm{~cm}$} & V1 & 19.6 & 18.6 & 14.97 & 15.01 & 76.42 & 80.71 & 9.57 & 9.9 \\
\hline & V2 & 19.1 & 18.2 & 14.76 & 14.82 & 77.24 & 81.42 & 9.5 & 9.83 \\
\hline & V3 & 19.5 & 18.4 & 15.02 & 14.57 & 77.09 & 79.24 & 9.65 & 9.52 \\
\hline & V4 & 19.5 & 19.6 & 16.22 & 17.47 & 82.13 & 89.19 & 10.81 & 12.13 \\
\hline & V5 & 18.95 & 18.5 & 14.35 & 15.06 & 75.77 & 81.44 & 9.13 & 9.99 \\
\hline \multicolumn{2}{|c|}{ LSD at $5 \%$ level } & NS & NS & 0.94 & 0.81 & 6.07 & NS & 0.97 & 0.8 \\
\hline
\end{tabular}

Table 2: Brix, sucrose, purity and sugar recovery percentages of the tested sugarcane varieties as affected by inter-row spacing and their interactions, in the plant cane, PC (2016-2017) and its 1st ratoon crop, FR (2017-2018).

The results indicated that 'G.2003-47' promising variety gave the highest sucrose $\%$ (16.48 and $17.31 \%$ ) in the plant and 1st ratoon cane, respectively, compared with the other varieties. However, the difference in sucrose $\%$ between the commercial variety 'G.T.54-9' and each 'G.2004-27' and 'G.84-47' promising varieties was insignificant, in the plant and $1^{\text {st }}$ ratoon cane. Such varietal differences among cane genotypes in sucrose $\%$ were reported by El-Geddawy, et al., Galal, et al., [4,5].

Sucrose \% was significantly influenced by the interaction between the tested cane varieties and interrow spacing in the plant and 1st ratoon cane, there was insignificant variance between 'G.2003-47' and each 'G.2004-27' and 'G.84-47' in sucrose\% in sugarcane planted in rows spaced at $100 \mathrm{~cm}$, in the plant and 1st ratoon crop. Meantime, 'G.2003-47' surpassed 'G.2004-27' and 'G.84-47' in this trait when they were planted in rows of 80 and $120 \mathrm{~cm}$ space, in the plant and 1st ratoon cane.

\section{Purity Percentage}

Data in Table 2 reveal that inter-row spacing had a significant influence on purity\% in the plant cane only. Planting sugarcane in rows of $100 \mathrm{~cm}$ apart resulted in 12.91 and $9.75 \%$ higher than that found in rows of 80 and/or $120 \mathrm{~cm}$ space, successively. These results are in agreement with those obtained by El-Sogheir and Abdel Fattah [3].

The results in Table 2 indicate that the evaluated sugarcane varieties varied significantly in purity\%. 'G.2003-47' promising variety produced the highest purity\% (83.34 and 87.56\%) in the plant and 1st ratoon cane, respectively. Meanwhile, there was insignificant difference in purity\% obtained from 'G.2003-47' and 'G.2004-27' grown as a plant cane crop. However, the difference in purity\% between 'G.2004-27' promising variety and each the commercial variety 'G.T.54-9' and 'G.84-47' promising variety were insignificant, in the plant and 1st ratoon cane. These results are in line with those obtained by El-Geddawy, et al. and Fahmy, et al. [4,10].

Purity \% was significantly influenced by the interaction between the tested cane varieties and interrow spacing in the plant cane only, there was insignificant variance between 'G.2003-47' and each 'G.2004-27' and 'G.84-47' in purity \% in sugarcane planted in rows spaced at 100 and $120 \mathrm{~cm}$. Meantime, 'G.84-47' variety recorded 10.14 and $14.69 \%$ less in purity $\%$ than that obtained from 'G.2003-47' and 'G.2004-27' respectively, when they were planted in rows of $80 \mathrm{~cm}$ space. 


\section{Open Access Journal of Agricultural Research}

\section{Sugar Recovery Percentage}

Data in Table 2 show that the sugar recovery\% was significantly affected by inter-row spacing in the plant and 1st ratoon cane crops. Growing sugarcane in rows of 100 $\mathrm{cm}$ increased the sugar recovery $\%$ by 2.25 and $1.72 \%$ in the plant cane and 0.40 and $0.92 \%$ in 1st ratoon cane, respectively, compared with that recorded in planting sugarcane at 80 and/or $120 \mathrm{~cm}$ inter-row spacing. However, the difference between 80 and $100 \mathrm{~cm}$ in their influence on sugar recovery\% was insignificant, in the plant and 1st ratoon cane. These results are in harmony with that found by Sharar, et al. and Asokan et al., $[12,13]$.

Sugar recovery $\%$ affected significantly by the tested sugarcane varieties, 'G.2003-47' promising variety gave the highest sugar recovery\% (11.07 and $11.91 \%$ ) in the plant and 1st ratoon cane, respectively. Meanwhile, there was insignificant difference in sugar recovery $\%$ obtained from 'G.2003-47' and 'G.2004-27' grown as a plant cane crop. However, the difference in sugar recovery\% between 'G.2004-27' promising variety and each the commercial variety 'G.T.54-9' and 'G.84-47' variety was insignificant, in the plant and 1st ratoon cane. These finding are in accordance with those obtained by Galal, et al. and El-Bakry $[5,6]$.

Sugar recovery\% was significantly influenced by the interaction between the tested cane varieties and interrow spacing in the plant and 1st ratoon cane, there was insignificant variance between 'G.2003-47' and each 'G.2004-27' and 'G.84-47' in sugar recovery\% in sugarcane planted in rows spaced at $100 \mathrm{~cm}$, in the plant and $1^{\text {st }}$ ratoon crop. However, 'G.2003-47'surpassed 'G.2004-27' and 'G.84-47' in this trait when they were planted in rows of 80 and/or $120 \mathrm{~cm}$ space, in the plant and $1^{\text {st }}$ ratoon cane.

\section{Cane Yield/ha}

Data in Table 3 show that cane yield/ha was significantly affected by inter-row spacing in the plant and its 1st ratoon cane crops. Planting sugarcane in rows of $100 \mathrm{~cm}$ apart increased the cane yield/ha by 10.51 and
29.02 ton of canes/ha over that gained in case of growing sugarcane in rows of 80 and/or $120 \mathrm{~cm}$ space, respectively, in the plant cane, corresponding to 15.28 and 24.99 ton of canes/ha in $1^{\text {st }}$ ratoon cane. The difference between 80 and $100 \mathrm{~cm}$ in their influence on cane yield/ha was insignificant, in the plant cane. Similar results were given by Banerjee, et al. and abd El-Lattief $[7,9]$.

Promising sugarcane variety 'G.2004-27' exhibited the superiority in cane yield recording significant increases amounted to $29.46,17.46,22.12$ and 42.76 tons/ha higher than those produced by 'G.T.54-9', 'G.84-47', 'G.2003-47' and 'C.57-14' varieties respectively, in the plant cane, corresponding to $31.28,19.41,26.75$ and 51.09 tons/ha in 1st ratoon cane. However, the difference in this trait between G.84-47 and 'G.2003-47' was insignificant, in the plant cane. Varietal differences in cane yield were observed by El-Sogheir and Abd el Fattah and Fahmy, et al. $[3,10]$.

Cane yield was significantly influenced by the interaction between inter-row spacing and tested cane varieties in the plant and $1^{\text {st }}$ ratoon cane. The difference between 'G.T.54-9' and 'G.2003-47' in cane yield/ha was insignificant when they were planted in rows of $120 \mathrm{~cm}$ spaced, in the plant cane as well as at 80,100 and $120 \mathrm{~cm}$ in 1st ratoon cane. However, 'G.2003-47' surpassed 'G.T.54-9' in this trait when they were planted in rows of 80 and $100 \mathrm{~cm}$ spaced.

\section{Sugar Yield/ha}

Data in Table 3 clear that the sugar yield/ha was significantly affected by inter-row spacing in the plant and its $1^{\text {st }}$ ratoon cane crops. Growing sugarcane in rows of $100 \mathrm{~cm}$ apart increased the sugar yield/ha by 4.17 and 5.36 ton of sugar/ha over that gained in case of growing sugarcane in rows of 80 and/or $120 \mathrm{~cm}$ space, respectively, in the plant cane, corresponding to 2.29 and 4.04 ton of sugar/ha in $1^{\text {st }}$ ratoon cane. Similar results were obtained by El-Geddawy, et al. and Pawar, et al. $[8,14]$.

\begin{tabular}{|c|c|c|c|c|c|c|}
\hline \multirow{2}{*}{ Treatments } & \multicolumn{2}{|c|}{ Cane yield/ha (ton) } & \multicolumn{2}{|c|}{ sugar yield/ ha (ton) } & \multicolumn{2}{|c|}{ Pokkah boeng disease (DS \%) } \\
\hline & PC & FR & PC & FR & PC & FR \\
\hline \multicolumn{7}{|c|}{ Row spacing } \\
\hline $80 \mathrm{~cm}$ & 131.08 & 135.68 & 12.15 & 14.65 & 3.92 & 3.92 \\
\hline $100 \mathrm{~cm}$ & 141.59 & 150.95 & 16.32 & 16.95 & 2.48 & 2.48 \\
\hline $120 \mathrm{~cm}$ & 112.57 & 125.96 & 10.96 & 12.91 & 2.24 & 2.08 \\
\hline LSD at $5 \%$ level & 13.85 & 5.13 & 1.74 & 1.25 & 0.14 & 0.23 \\
\hline
\end{tabular}




\section{Open Access Journal of Agricultural Research}

\begin{tabular}{|c|c|c|c|c|c|c|c|}
\hline \multicolumn{8}{|c|}{ Sugarcane varieties } \\
\hline \multicolumn{2}{|c|}{ ‘G.T.54-9' (V1) } & 121.31 & 131.96 & 12.26 & 13.73 & 4.8 & 5.6 \\
\hline \multicolumn{2}{|c|}{ 'G.2004-27' (V2) } & 150.77 & 163.24 & 15.7 & 17.18 & 1.73 & 1.47 \\
\hline \multicolumn{2}{|c|}{ ‘G.84-47’ (V3) } & 133.31 & 143.82 & 13.38 & 15.55 & 3.47 & 2.8 \\
\hline \multicolumn{2}{|c|}{ ‘G.2003-47' (V4) } & 128.65 & 136.49 & 14.29 & 16.25 & 1.87 & 1.87 \\
\hline \multicolumn{2}{|c|}{ 'C.57-14' (V5) } & 108.01 & 112.14 & 10.08 & 11.48 & 2.53 & 2.4 \\
\hline \multicolumn{2}{|c|}{ LSD at $5 \%$ level } & 8.05 & 5.25 & 0.96 & 0.88 & 0.43 & 0.44 \\
\hline \multicolumn{8}{|c|}{ Interaction } \\
\hline \multirow{5}{*}{$80 \mathrm{~cm}$} & V1 & 121.58 & 129.77 & 11.8 & 14.09 & 5.6 & 8.4 \\
\hline & V2 & 155.85 & 157.2 & 14.93 & 16.28 & 2.4 & 2 \\
\hline & V3 & 124.1 & 134.95 & 9.58 & 14.97 & 5.2 & 3.2 \\
\hline & V4 & 137.41 & 138.07 & 14.72 & 16.22 & 2.4 & 2.8 \\
\hline & V5 & 116.44 & 118.41 & 9.71 & 11.71 & 4 & 3.2 \\
\hline \multirow{5}{*}{$100 \mathrm{~cm}$} & V1 & 124.55 & 141.4 & 13.7 & 14.75 & 4.8 & 4.4 \\
\hline & V2 & 163.61 & 178.05 & 19.56 & 20.08 & 1.6 & 1.6 \\
\hline & V3 & 154.58 & 158.97 & 18.9 & 18.59 & 2.8 & 2.4 \\
\hline & V4 & 143.59 & 148.93 & 16.76 & 17.66 & 1.6 & 1.6 \\
\hline & V5 & 121.62 & 127.41 & 12.68 & 13.65 & 1.6 & 2.4 \\
\hline \multirow{5}{*}{$120 \mathrm{~cm}$} & V1 & 117.81 & 124.71 & 11.28 & 12.34 & 4 & 4 \\
\hline & V2 & 132.86 & 154.47 & 12.61 & 15.18 & 1.2 & 0.8 \\
\hline & V3 & 121.26 & 137.56 & 11.67 & 13.09 & 2.4 & 2.8 \\
\hline & V4 & 104.96 & 122.47 & 11.38 & 14.85 & 1.6 & 1.2 \\
\hline & V5 & 85.98 & 90.62 & 7.86 & 9.08 & 2 & 1.6 \\
\hline \multicolumn{2}{|c|}{ LSD at $5 \%$ level } & 13.33 & 8.7 & 1.58 & NS & 0.75 & 0.76 \\
\hline
\end{tabular}

Table 3: Cane yield/ha, sugar yield/ha and pokkah boeng disease (DS \%) of the tested sugarcane varieties as affected by inter-row spacing and their interactions, in the plant cane, PC (2016-2017) and its 1st ratoon crop, FR (2017-2018).

Promising sugarcane variety 'G.2004-27' exhibited the superiority in sugar yield recording significant increases amounted to $3.44,2.32,1.41$ and 5.62 tons/ha higher than those produced by 'G.T.54-9', 'G.84-47', 'G.2003-47' and 'C.57-14' varieties respectively, in the plant cane, corresponding to $3.45,1.63,0.93$ and 5.70 tons/ha in $1^{\text {st }}$ ratoon cane. However, the difference in this trait between 'G.84-47' and 'G.2003-47' was insignificant, in the plant cane. Such varietal differences were reported by Abd ElLattief and El-Bakry [6,9].

Sugar yield ton/ha was significantly influenced by the interaction between the tested cane varieties and interrow spacing in the plant cane only, there was insignificant variance between the commercial variety 'G.T.54-9' and each 'G.2004-27' and 'G.2003-47' in sugar yield/ha in planted in rows spaced at $120 \mathrm{~cm}$. However, sugarcane varieties 'G.2004-27' and 'G.2003-47' surpassed in sugar yield/ha recording significant increases amounted to 3.13 and 2.92 ton/ha as well as 5.86 and 3.06 ton/ha higher than those produces by commercial variety 'G.T.54-9' when they were planted in rows of 80 and $100 \mathrm{~cm}$ space, respectively. These results are in agreement with those reported by El-Sogheir and Abd el Fattah [3].

\section{Susceptibility of Sugarcane Promising Varieties to Infect with Pokkah Boeng Disease}

Infection with the pokkah boeng disease was determined under natural conditions in the successive seasons 2016/17 (plant cane) and 2017/18 (first ratoon) [27].

\section{Pokkah Boeng Disease}

Data in Table 3 and Figure 1 show that increasing inter-row spacing from 80 to $120 \mathrm{~cm}$ led to a significant reduction in disease severity \% of pokkah boeng disease in the plant and 1st ratoon crops, this reduction amounted by 1.68 and $0.24 \%$ in the plant cane, correspond to 1.84 and $0.40 \%$ DS\% in the 1 st ratoon crop, respectively, compared with that recorded in case of planting sugarcane at 80 and/or $100 \mathrm{~cm}$ spaced. These results are in agreement with those obtained by Vishwakarma, et al. they found that paired row or wider 


\section{Open Access Journal of Agricultural Research}

spacing planting of sugarcane is necessary to facilitate the plant protection operations [22].

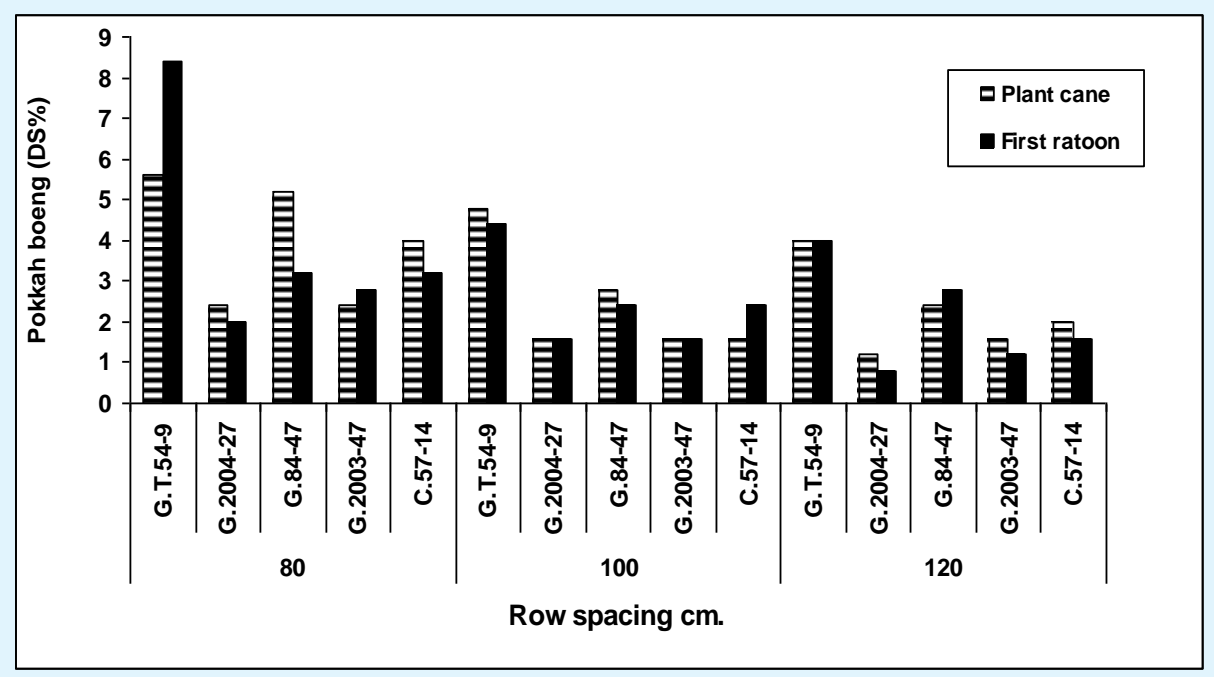

Figure 1: Susceptibility categories of certain sugarcane promising varieties to infection with pokkah boeng disease under natural conditions in the successive seasons 2016/2017 (plant cane) and 2017/2018 (first ratoon).

Variation in susceptibility among sugarcane varieties to infection with pokkah boeng disease was reported by Cuenya, et al. and Osman, et al. [21,28]. The tested promising varieties differed significantly in infection with pokkah boeng disease in the plant and 1st ratoon cane. The tested five sugarcane varieties were susceptible to infection with pokkah boeng disease with different degrees of susceptibility. The commercial variety 'G.T.549' gave the highest DS\% of pokkah boeng disease $(4.80$ and $5.60 \%$ ) in plant and 1st ratoon crop, respectively. While 'G. 2004-27' variety recorded the least DS\% of pokkah boeng disease (1.73 and $1.47 \%)$ in plant and 1 st ratoon crop, respectively. Also, insignificant difference was observed between promising variety 'G.2003-47' and 'G. 2004-27' in this trait, in the plant and $1^{\text {st }}$ ratoon cane. Variation in susceptibility among sugarcane varieties to infection with pokkah boeng disease was reported by Cuenya, et al. and Osman, et al. [21,28,29].

Disease severity \% was significantly influenced by the interaction between inter-row spacing and tested cane varieties in the plant and 1st ratoon cane, there was insignificant variance between 'G.2004-27' and 'G.200347 ' in disease severity \% of pokkah boeng disease in sugarcane grown under different inter-rows spacing in the plant and 1st ratoon crop except planting at $80 \mathrm{~cm} \mathrm{1st}$ ratoon crop was significant.

\section{Conclusion}

Under conditions of this investigation, planting sugarcane variety 'G.2004-27' in rows spaced at $100 \mathrm{~cm}$ can be recommended to obtain the highest cane and sugar yields/ha and the lowest percentage of infection with pokkah boeng disease (Fusarium moniliforme Sheldon).

\section{References}

1. Ahmed ZA, Ahmed AM, Osman MSH (2011) Optimum inter-row spacing and number of ploughings for two promising sugarcane varieties. Egypt J Agric Res 89(1): 301-316.

2. El-Shafai AMA, Ismail AMA (2006) Effect of row spacing on yield and quality of some promising sugarcane varieties. Egypt J Appl Sci 21 (11): 32-46.

3. El-Sogheir KS, Abd El-Fattah AI (2009) Evaluation of some promising sugar cane varieties under different row spacing. J Biol Chem Environ Sci 4(1): 285-318.

4. El-Geddawy IH, Dalia IH, Makhlouf BSI, Bekheet MA (2015) Performance of some sugar cane promising varieties under different seed sett rates and 


\section{Open Access Journal of Agricultural Research}

potassium fertilization. Int J Curr Microbiol Appl Sci 4 (11): 92-110.

5. Galal MOA, Osman MAM, Fahmy AM, El-Mohamed A (2017) Performance of some sugarcane genotypes under different planting methods and natural infestation with insects and diseases. Egypt. J Plant Breed 21(4): 843-859.

6. El-Bakry A (2018) Effect of row spacing on some sugarcane varieties yield and juice quality. J Biol Chem Environ Sci 13(2): 105-120.

7. Banerjee K, Pramanik BR, Puste AM (2012) Effect of different row spacing on ratoonability of high sugar genotypes of sugarcane hybrids. J Crop Weed 8(2): 77-79.

8. El-Geddawy IH, Darweish DG, El-Sherbiny AA, ElHady EEA (2002) Effect of row spacing and number of buds/ setts on growth characters of ratoon crops for some sugar Cane varieties. Pakistan Sugar J 17(3): 714.

9. El-Lattief EAA (2016) Yield and yield attributes of sugarcane as affected by some crop management treatments. I J Res Eng Appl Sci 6(12): 11-19.

10. Fahmy AM, Osman MAM, Galal MOA (2017) Yield, Quality and Natural Infestation with Insect and Disease of Four Sugarcane Varieties as Affected by Different Levels of Potassium Fertilization. J Plant Prot and Path Mansoura Univ 8(12): 687-693.

11. Chakrawal D, Kumar N (2014) Physio-agronomic analysis of sugarcane (Saccharum spp. hybrid complex) varieties under different planting geometry. Ind J Sugarcane Technol 29(2): 67-71.

12. Sharar MS, Ayub M, Choudhry MA, Amin MMZ, Khalid MM (2000) Morph qualitative traits of sugarcane (Saccharum officinarum L.) varieties as influenced by seeding density. Pak J Biol Sci 3: 1156-1157.

13. Asokan S, Murthi AN, Mahadevaswamy M (2005) Effect of nitrogen level and row spacing on yield, CCS and nitrogen uptake in different sugarcane varieties. Sugar Technol 7(2-3): 44-47.

14. Pawar MW, More DB, Amodkar VT, Joshi S (2005) Effect of intersettling spacing on sugarcane yield and quality. Ind J Sugar Tech 7(1): 87-89.
15. Maqsood M, Iqbal M, Tayyab M (2005) Comparative Productivity Performance of Sugarcane (Saccharum officinarum, L.) Sown in Different Planting Patterns at Farmer's Field. Pakistan J Agric Sci 42(3-4): 25-28.

16. Devi TC, Lakshmi MB, Naidu NV (2005) Response of New Sugarcane Genotypes to Wide Row Spacing. Sugar Technol 7(4): 154-156.

17. Mehareb EM, Osman MAM, Fahmy AM (2018) Screening sugarcane genotypes for the lesser sugarcane borer, chilo agamemnon bels., and four main diseases resistance in Egypt. Egypt J Plant Breed 22(4): 659-683.

18. Walker JH, Went FAFC (1896) Overzicht van de ziekten van het suikerriet op Java. Arch Suikerind Ned Indie pp: 425-435.

19. Siti Nordahliawate MS, Nur Ain Izzati MZ, Azmi AR, Salleh B (2008) Distribution, morphological characterization and pathogenicity of Fusarium sacchari associated with pokkah boeng disease of sugarcane in Peninsular Malaysia. Pertanika J of Tropical Agric Sci 31(2): 279-286.

20. Mohammadi A, Reza FN, Nasrin NM (2012) Fusarium verticillioides from sugarcane, vegetative compatibility groups and pathogenicity. Plan Protec Sci 48(2): 80-84.

21. Osman MAM, Hassan MAE, El-Kholi MMA, Elneshar AA (2014) Reaction of certain sugarcane varieties to infection with pokkah boeng disease caused by Fusarium subglutenans. Assiut J Agri Sci 45(3): 65-77.

22. Vishwakarma SK, Kumar P, Nigam A, Singh A, Kumar A (2013) Pokkah Boeng: An Emerging Disease of Sugarcane. J Plant Pathol Microb 4(3): 1-5.

23. AOAC (1995) Association of official analytical chemists. Official methods of analysis, (16th Edn), Int, Washington, DC, USA.

24. Yadav RL, Sharma RK (1980) Effect of nitrogen level and harvesting date on quality characteristics and yield of four sugar cane genotypes. Indian J Agric Sci 50: 581-589.

25. Ramirez E, Nass H (2005) Status pokkah boeng (Fusarium moniliforme) in Yaracuy Yaritagua in the years 2003 to 2005 . 


\section{Open Access Journal of Agricultural Research}

26. Snedecor GW, Cochran WG (1981) Statistical Methods. 7th (Edn.), Iowa State Univ Press, Ames, Iowa, USA.

27. Comstock JC, Milligan SB (2007) Comparison of cl and cp germplasm reactions to sugarcane yellow leaf virus, leifsoniaxyli subsp. Xyli and Puccinia melanocephala. Journal American Society of Sugar Cane Technologists 27: 79-88.
28. Cuenya MI, Chavanne ER, Ostengo S, Garcia MB, Ahmed M, et al. (2011) Productive and phytosanitary TUC 95-10, a new sugarcane cultivar produced by the EEAOC. Avance Agroindustrial 32(4): 14-21.

29. Galal MOA, Abou-Salama AM, Teama EA, Ahmed AZ (2015) Yield response of late planted spring sugarcane to direct set sowing and transplanting. Sci J King Faisal Univ 16(1): 75-94.

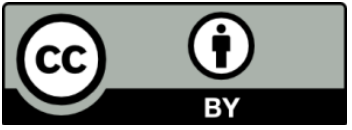

